\title{
Cereals and Societies: Millet, Wheat, and Society in North China in the Very Long Term
}

\section{By Hongzhong He, Joseph Lawson, Martin Bell, and Fuping Hui.}

\begin{abstract}
:
This paper outlines a very longue durée history of three of North China's most important cereal crops - broomcorn and foxtail millet, and wheat - to illustrate their place within broader social-environmental formations, to illustrate the various biological and cultural factors that enable the spread of these crops, and the ways in which these crops and the patterns in which they are grown influenced the further development of the societies that grew them. This article aims to demonstrate that a very long-run approach raises new questions and clarifies the significance of particular transitions. It, firstly, charts the transition from broomcorn to foxtail millet cultivation in the late Neolithic; secondly, shows efforts to spread winter wheat often met some degree of resistance from farming communities; thirdly, considers the significance of the different processing requirements of wheat and millet, and their implications for social and economic development; and, fourthly, considers the debate over the spread of multiple-cropping systems to North China.
\end{abstract}

\section{Introduction}

Scholars have highlighted the importance of crops in comparative studies that seek to explain broad differences in development among various Eurasian societies over long periods of time. ${ }^{1}$ European crops — oats, barley, wheat, and rye — entailed the proliferation of mills, establishing the monasteries and magnates who owned them, and rudimentary mechanization, at the heart of European society. In contrast, the East Asian rice growing communities invested not in milling-machines, but in skilled labour. Scholars' treatment of Chinese agriculture focuses strongly on the rice regions, neglecting North China. Francesca Bray notes in passing that in North China "a pattern of technological development and relations of production rather similar to late medieval Europe started to emerge in the early centuries AD. ${ }^{2}$ But much less has been written from a global history perspective about the long-term development of this pattern, and the role of its key crops and cropping systems than has been written about the rice economies. This is also the case with most of the recent comparative studies of China and Europe in the 'Great Divergence' debate, which focus almost exclusively on the rice-growing Jiangnan as the region of China that was most commercially developed,

\footnotetext{
${ }^{1}$ Dietrich Vollrath, "The Agricultural Basis of Comparative Development," Journal of Economic Growth 16, no. 4 (2011): 343-370; Michael Mitterauer, Why Europe? The Medieval Origins of its Special Path (Chicago:

University of Chicago Press, 2010) ch. 1-2; Francesca Bray, The Rice Economies: Technology \& Development in Asian Societies (Berkeley: University of California Press, 1986), 113-139.

2 Bray, The Rice Economies, xv.
} 
and therefore, it is usually assumed, the region most suited to industrial development.

The purpose of this article is to outline a very longue durée history of three of North China's most important cereal crops — broomcorn and foxtail millet, and wheat — to outline their place within broader social-environmental formations to illustrate the various biological and cultural factors that enable the spread of these crops, and the ways in which these crops and the patterns in which they are grown influenced the further development of the societies that grew them. This article aims to demonstrate that a very long-run approach raises new questions and clarifies the significance of particular transitions. Our analysis includes the nonliterate societies of the distant past with more recent places for which there is written evidence because the distinction between literate and non-literate societies may have little ipso facto relevance to the history of the environment. It might be the case that literacy and its associated changes shaped agricultural history by, for example, generating rapid agricultural 'revolutions', but any such differences must be demonstrated in an analysis that also includes the non-literate past.

The notion of 'revolution' has been applied to agriculture change since Arnold Toynbee in the late nineteenth century, and debated extensively since. ${ }^{3}$ Despite the controversies that have surrounded the concept in the historiography of England, the idea of 'agricultural revolution' has been exported and applied to medieval China. Mark Elvin argued that one occurred in Tang and Song China, a view accepted by many other scholars including Mitterauer. ${ }^{4}$ Elvin and those who have followed him treat this medieval revolution in farming mostly as southern affair. The only Northern contribution he mentions was the rise of wheat farming in the North as a result of better milling technology, though this has not been explored in depth. ${ }^{5}$ Recently Ling Zhang has argued against the idea of an agricultural revolution in Song-era North China, making the case instead for gradual and modest change. ${ }^{6}$ This article aims in part to assess the applicability of the concept of 'revolution' to transitions in crops and cropping patterns in North China from earliest times to the nineteenth century.

The oldest cereal crop in North China was broomcorn millet ( $j i$ 穄, Panicum miliaceum), which was domesticated around 9000 BCE. This was replaced by foxtail millet ( shu 秘, Setaria italica) in the late Neolithic ( c. 5000 BCE), which in turn declined with the rise of wheat (mai 麥, Triticum spp.) over the first millennium CE. The rise of winter wheat cultivation led to more elaborate cropping patterns and year-round agriculture in the Yellow River basin, with important implications for statecraft and occupational structure. Winter wheat was also a new source of difference between the agricultural systems of the Central Plains and those further north. The rise of multiple-cropping in cereals in North China after

\footnotetext{
${ }^{3}$ For a summary of the early development of this idea, see Eric Kerridge, "The Agricultural Revolution Reconsidered," Agricultural History 43, no. 4 (1969): 463-476.

${ }^{4}$ Mark Elvin, The Pattern of the Chinese Past (Stanford: Stanford University Press, 1973), 113-131; Mitterauer, Why Europe? Ch. 2.

5 Elvin, The Pattern of the Chinese Past, 113.

${ }^{6}$ Ling Zhang, The River, the Plain, and the State: An Environmental Drama in Northern Song China, 1048-1128 (Cambridge: Cambridge University Press, 2016), 222-23.
} 
the Song Dynasty reinforced these changes.

\section{The Broomcorn to Foxtail Transition}

Broomcorn and foxtail millet were first domesticated in Northern China, with broomcorn preceding foxtail by up to two millennia. Early broomcorn remains have been found over a broad area, including the Nanzhuangtou site (ca. 11,500-11,000 BP), Donghulin site (ca. 11,000-9,500 BP), and the Cishan site (ca. 10,300 and 8,700 BP), the former two of which are well to the north of the prominent Neolithic sites of the mid-Yellow River area (figure 1). ${ }^{7}$ Foxtail millet appears somewhat later at the Xinglonggou site in present-day Inner Mongolia, dating to ca. 8,000-7,500 BP; though only 10 grains of foxtail millet and more than 1,500 grains of broomcorn millet have been recovered from this site. ${ }^{8}$ Excavations at the Yuezhuang site (ca. 6,900 \pm 35 BP) and the first and second periods of Dadiwan site (ca. 7,800$6,000 \mathrm{BP}$ ) also indicate that the most important crop in these communities was broomcorn. ${ }^{9}$

\footnotetext{
7 Zhao Zhijun 赵志军, “You guanyu nongye qiyuan he wenming qiyuan de zhiwu kaoguxue yanjiu 有关农业起 源和文明起源的植物考古学研究, "Shehui kexue pinglun 社会科学评论, 2005(2): 82-91; Houyuan Lu, Jianping Zhang et al., "Earliest Domestication of Common Millet (Panicum miliaceum) in East Asia Extended to 10,000 Years Ago," Proceedings of the National Academy of Sciences USA [hereafter, PNAS] 106, no. 18 (2009), 7369-7370. Since Lu et al, scholars have extended the earliest millet cultivation to 11,5000 years ago: Xiaoyan Yang, Zhiwei Wan, et al., "Early Millet Use in Northern China," PNAS 109, no. 10 (2012);

8 Zhao Zhijun, "You guanyu nongye qiyuan," 82-91; Sun Yonggang 孙永刚, “Xi Liao He shangyou shengtai huanjing bianqian yu Zhongguo beifang hanzuo nongye qiyuan 西辽河上游生态环境变迁与中国北方旱作农 业起源,” Gan han qu ziyuan yu huanjing 干旱区资源与环境, 2009(1): 60-63.

${ }^{9}$ Crawford, G.W., Chen Xuexiang 陈雪香, Luan Fengshi 栾丰实, Wang Jianhua 王建华, “Shandong Jinan Changqingyuezhuang yizhi zhiwu yicun de chubu fenxi 山东济南长清月庄遗址植物遗存的初步分析, ” Jiang Han kaogu 江汉考古, 2013(2): 107-116; Liu Changjiang 刘长江, Kong Zhaochen 孔昭宸, and Lang Shude 朗树德, “Dadiwan yizhi nongye zhiwu yicun yu renlei shengtai de huanjing tantao 大地湾遗址农业植物遗存 与人类生存的环境探讨,” Zhongyuan wenwu 中原文物, 2004(4): 26-30.
} 


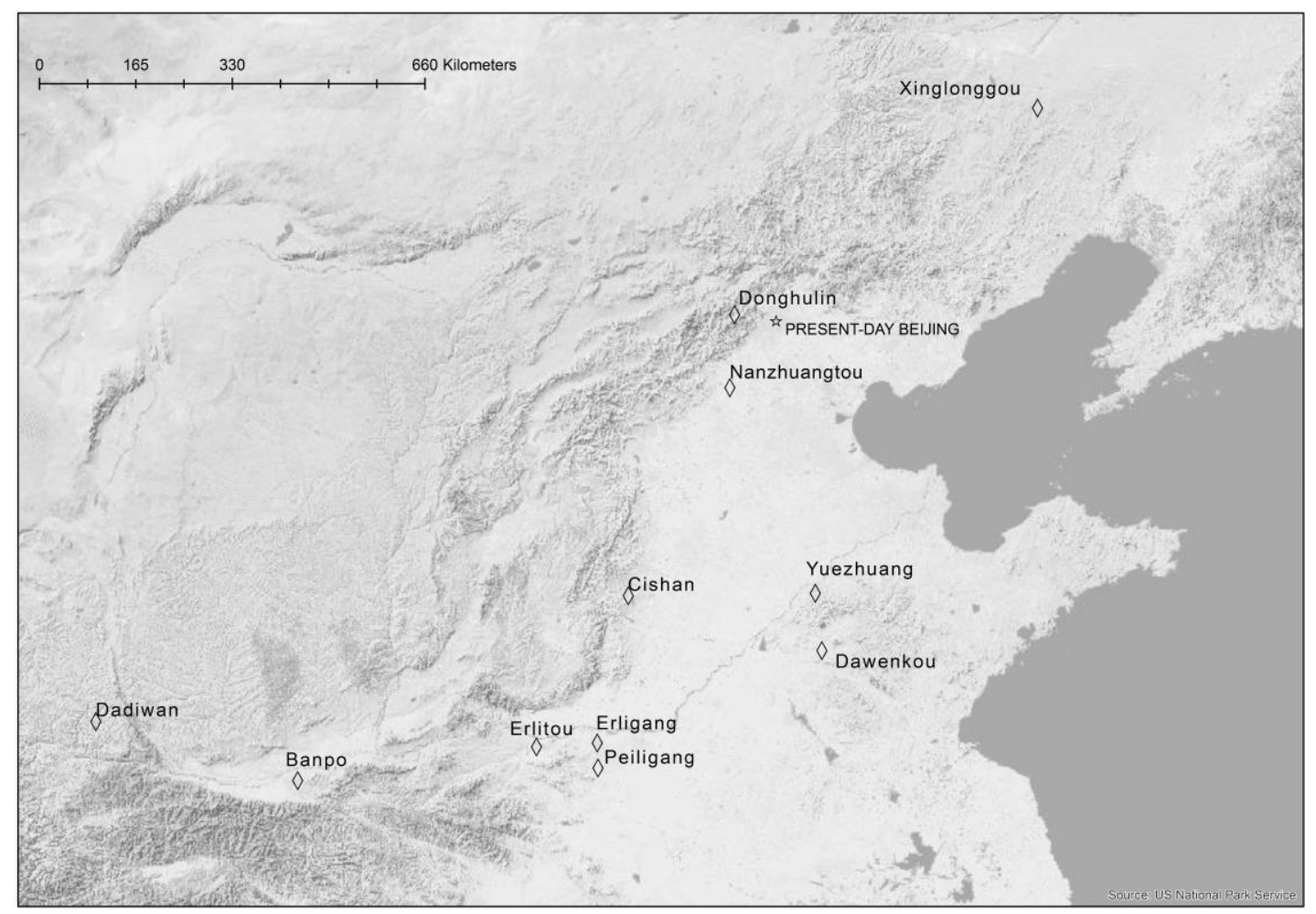

Figure 1: Prehistoric sites with grain finds mentioned in the text. Source for base map: US National Park Service.

Broomcorn millet was a better match for the environment and economy of the first farmers. Although both millets have a short growing season and are relatively resistant to drought, broomcorn millet is more drought and cold tolerant than foxtail millet and its growth period is much shorter. ${ }^{10}$ All the early millet sites are in hilly areas, on the edges of the chain of mountains that runs through Shanxi and western Hebei. The interval from 11,000 to 8,000 BP saw cooling throughout the Northern Hemisphere that reduced the tree limit in Sweden and extended glaciers in Europe and North America. ${ }^{11}$ Unlike winter varieties of wheat, neither millet can tolerate frost during its growth period, and of the two, the cooling climate probably suited broomcorn better, and may even have reduced the number of frost-free days to below that required for late-maturing varieties of foxtail in some locations around the Donghulin, Nanzhuangtou, and Xinglonggou sites. Moreover, the earliest agricultural communities depended chiefly on gathering and hunting and used very little agricultural technology. ${ }^{12}$ With very limited ability to modify soils through tilling, broomcorn millet was suitable for cultivation because of its lower soil fertility requirement and stronger ability to

\footnotetext{
${ }^{10}$ Cheng Bingwen 程秉文, “Zhongguo mizi chanye fazhan xianzhuang yu duice 中国糜子产业发展现状与对 策” in Zhongguo xiao zaliang chanye fazhan baogao 中国小杂粮产业发展报告, ed. Chai Yan 柴岩 and Wan Fushi 万富世 (Beijing: Zhongguonongyekexuechubanshe, 2007): 52-59

11 Paul Mayewski, Eelco Rohling, et al., "Holocene climate variability," Quaternary Research 62 (2004): 249.

12 Zhao Zhijun 赵志军, “You guanyu nongye qiyuan he wenming qiyuan de zhiwu kaogu xue yanjiu 有关农业 起源和文明起源的植物考古学研究,”Shehui kexue pinglun 社会科学评论, no. 2 (2005): 82-91.
} 
cope with weeds.

Broomcorn became a minor crop in the late Neolithic, but farming communities in the north retained a memory of its properties as a drought resistant crop that grew well on hillsides and land that was marginal for other cereals thousands of years after it ceased to be a primary crop. These qualities were identified in agriculture literature such as Essential Methods of the Common People (Qi min yao shu 齊民要術, ca. 533-544 CE). This book's author identified broomcorn millet as the best crop for newly cleared land. ${ }^{13}$ It continued to be used as a 'pioneer crop' on such land through to the end of the Qing Dynasty (1644-1911 CE)..$^{14}$

Archaeological work shows a gradual increase in foxtail millet cultivation from the late Neolithic (ca. 5000-3500 BCE). Sites become denser and more geographically dispersed reaching west to Xinjiang and Qinghai, east to Kaohsiung in Taiwan, south to Dali in Yunnan Province, north to Shanxi and Hebei, in an area that encompasses many different archaeological cultures including Yangshao (Yellow River area, 5000-3000 BCE), Dawenkou (Shandong, 4100-2600 BCE), Hongshan (Manchuria and Inner Mongolia 4700-2900 BCE) and Majiayao (Gansu and Qinghai, 3000-2000 BCE. ${ }^{15}$ Grain buried with the dead in the late Yangshao Culture suggests that foxtail millet was already dominant in the Yellow River area at that time. ${ }^{16}$ Remains of foxtail millet have been found in many houses, cellars and tombs of Banpo site (early Yangshao, ca. 4800-4300 BCE), where one of the cellars had about one cubic meter of foxtail millet seeds. ${ }^{17}$ The overwhelming majority of seeds excavated from the Dadiwan site of the late Yangshao culture are foxtail millet; in one pit, broomcorn millet seeds account for only 0.7 percent of the total. ${ }^{18}$ Foxtail was also frequent at Sanlihe site of the late Dawenkou Culture. ${ }^{19}$ Some Yangshao sites have more broomcorn, but still less than foxtail: at the Wangjiazui site of the late Yangshao Culture eight foxtail and two broomcorn seeds were recorded by flotation. ${ }^{20}$ One estimate suggests that broomcorn may have accounted for as little as 2.5 percent of the total food crops in the Yangshao and Longshan eras (5000-1900 $\mathrm{BCE}){ }^{21}$

The picture in the archaeological record is consistent with that from the earliest textual

\footnotetext{
13 Jia Sixie 贾思劦思, Mou Qiyu 缪启愉校释, Qi min yao shu jiaoshe 齐民要术校释 (Beijing: Nongye chubanshe, 1982): 74, 92.

${ }^{14}$ Lillian Li, Fighting Famine in North China, 94.

${ }^{15}$ He Hongzhong 何红中 and Hui Fuping 惠富平, Zhongguo gudai su zuo shi 中国古代粟作史 (Beijing: Zhongguo nongye kexue jishu chubanshe, 2015), 28.

${ }^{16} \mathrm{He}$ and Hui, Zhongguo gudai su zuo shi, 29

${ }^{17}$ Chen Wenhua 陈文华, Nongye kaogu 农业考古 (Beijing: Wenwu chubanshe, 2002), 43.

${ }^{18}$ Liu Changjiang 刘长江, Kong Zhaochen 孔昭宸, and Lang Shude 朗树德, “Dadiwan yizhi nongye zhiwu yicun yu renlei shengcun de huanjing tantao 大地湾遗址农业植物遗存与人类生存的环境探讨, ” Zhongyuan wenwu 中原文物, 2004(4): 26-30.

${ }^{19}$ Chen Wenhua, Zhongguo nongye kaogu tulu 中国农业考古图录 (Nanchang: Jiangxi kexue jishu chubanshe, 1994), 29.

${ }^{20}$ He and Hui, Zhongguo gudai su zuo shi, 29

${ }^{21}$ Liu Changjiang 刘长江, Jin Guiyun 靳桂云, Kong Zhaochen 孔昭宸, Zhiwu kaogu一zhongzi he guoshi yanjiu 植物考古——种子和果实研究 (Beijing: Kexue chubanshe, 2008), 167.
} 
record. Research on the Oracle Bones from the Yin ruins (ca. 1319-1046 BCE) suggests that foxtail millet was the most widely cultivated and consumed crop in the late Shang. ${ }^{22}$ In the Book of Songs (Shi jing 詩經 ca. 1100-700 BCE), references to foxtail millet far exceed those to broomcorn millet. The Spring and Autumn Annals of Master Lü (Lü shi chun qiu 呂 氏春秋 ca. 247-239 BCE), The Book of Rites (Li ji 禮記), The Book of Fan Shengzhi (Fan Shengzhi shu 氾勝之書, first century BCE) and Essential Methods of the Common People, all classify foxtail millet as the most important crop. Zheng Xuan's 鄭玄 (127-200 CE) annotations on the Rites of Zhou (Zhou li 周禮, second century BCE) indicate that foxtail millet was the main stored grain of 'nine cereals'. ${ }^{23}$

The rise of foxtail millet over broomcorn was a component of a broad social transition that involved population increase, technological change, and a growing reliance on agriculture. Evidence suggests that millet made up a significant component of diet of only one pre-5000 BCE culture (Xinglonggou). ${ }^{24}$ In the Yangshao Culture and Longshan Cultures (mid and lower Yellow River region, 2900-1900 BCE), C4 plants (a group that includes millets) made up around 50 percent of communities' diets, according to isotopic results obtained during radiocarbon dating. ${ }^{25}$ The millets were the only $\mathrm{C} 4$ plants that could have been part of the diet of Yangshao and Longshan settlements, so at least half of these communities' diets must have come from cultivated crops. ${ }^{26}$ For societies that depended on agriculture for half their food, foxtail had the advantage of much higher per-hectare yields. Calculations based on The Art of War by Sunzi (Sun Zi bing fa 孫子兵法, finished about in the fourth to third century BCE), Guanzi (管子, edited in the first century BCE) and Standard History of the Han (Han shu 漢書, first century CE), indicate that the yield of broomcorn millet was only equivalent to around half that of foxtail millet, which was about 91 jin per $m u(682.5 \mathrm{~kg}$ per ha). ${ }^{27}$ There is a similar difference in yields of broomcorn and foxtail millet today. ${ }^{28}$ Foxtail not only provided more food per acre than broomcorn, it also demanded more labour because it is less resistant to weeds. Essential Methods of the Common People, for example, stressed

\footnotetext{
${ }^{22}$ Wen Shaofeng 温少峰, Yuan Tingdong 袁庭栋, Yin xu bu ci yanjiu一kexue jishu pian 殷墟卜辞研究——科 学技术篇 (Chengdu: Sichuan sheng shehui kexue chubanshe, 1983), 166-172.

${ }^{23}$ Zheng Xuan 郑玄, Zhou li zhu shu 周礼注疏, ed. Jia Gongyan 贾公彦 (Beijing: Beijing daxue chubanshe, 2000): 504.

24 Wang Yong 王勇, “Xiaomi de yingyang jiazhi ji Nei Menggu xiaomi shengchan jiagong xianzhuang 小米的营 养价值及内蒙古小米生产加工现状” PhD dissertation, (Inner Mongolia University, 2010): 5.

${ }^{25}$ Cai Lianzhen 蔡莲珍, Qiu Shihua 仇士华, “Tan shisan ceding he gudai ship u yanjiu 碳十三测定和古代食 谱研究," Nongye kaogu 农业考古, no. 10 (1984): 949-955; Qian Yaopeng 钱耀鹏, “Lüe lun Zhongguo shiqian nongye de fazhan ji qi tedian 略论中国史前农业的发展及其特点, ”Nongye kaogu 农业考古, 2000(1): 104111.

${ }^{26}$ Xinyi Liu, Dorian Q. Fuller, and Martin Jones, "Early Agriculture in China," in Graeme Barker and Candice Goucher (ed.), The Cambridge World History, volume 2:A World With Agriculture, 12,000 BCE-500 CE (Cambridge: Cambridge University Press ), 321.

27 Wan Jianzhong 万建中, Zhongguo yin shi wenhua 中国饮食文化 (Beijing: Zhongyang bianyi chubanshe, 2011): 24; He and Hui, Zhongguo gudai su zuo shi, 36.

28 Yang Wenzhi 杨文治 and Yu Cunzu 余存祖, Huang tu gaoyuan quyu zhili yu jiazhi 黄土高原区域治理与评 价 (Beijing: kexue chubanshe, 1992): 73-124.
} 
the need for considerably more hoeing work for foxtail millet. ${ }^{29}$ In the longue durée of Chinese agricultural history, the transition to foxtail millet was the first of a series of intensifications of agriculture that accompanied eras of population growth.

The societal change that involved the spread of foxtail millet also involved a shift in agricultural tools and methods. Wells had special importance for the spread of foxtail millet as it requires much more water over a longer growing period than broomcorn millet. ${ }^{30}$ The earliest wells appear to have been dug in the Peiligang culture around $5480 \mathrm{BCE}$, around the time of the spread of foxtail millet. Wells have been found in many sites in the North China plain from the Longshan culture (ca. 5200-1850 BCE) and the Erlitou and Erligang cultures (ca. 1900-1300 BCE). ${ }^{31}$ Several wells from the Longshan period and later are more than ten meters deep, while the deepest known pre-Longshan well was around six meters, which suggests the extension of agriculture into areas of deeper groundwater, and possibly the development of new well-digging techniques. ${ }^{32}$ The earliest texts note the rise of well construction in the Xia and Shang dynasties (c. 2070-1046 BCE). As is typical of agricultural innovations in ancient records, the spread of well construction is attributed to agents of political authority. Genealogies (Shiben 世本, finished around 234-228 BCE) indicates that Yi Yin 伊尹 (generally placed around 1700-1600 century BCE) taught the people to drill wells for irrigation during the drought of Tang of the Shang Dynasty. ${ }^{33}$ On present evidence, it is impossible to tell whether this is the result of a later narrative of a beneficent state backprojecting a genealogy of official achievements, or a distant reflection of the actual importance of political authority in the spread of agricultural technology, which may not, if James Scott is correct, have been welcomed by those who were governed. ${ }^{34}$ Alongside wells, other agricultural technology shows important development in the foxtail millet Neolithic cultures. The inhabitants of the Taosi 陶寺 site in Shanxi, for example, began using triangular stone ploughs around 4200-4000 BP, around the time to which the Xia dynasty is traditionally attributed. $^{35}$

\section{The Rise of Wheat}

\footnotetext{
${ }^{29}$ Qi min yao shu, juan 2, 3 .

30 Chai Yan 柴岩, Mi zi 糜子 (Beijing 北京: Zhongguo nongye chubanshe, 1999): 195.

31 Zheng Hongchun 郑洪春, “Kaogu faxian de shuijing yu 'zao jing er guan' 考古发现的水井与“丵井而灌,” Wen bo 文博, 1996(5): 50-53; Fu Hailong 付海龙, “Shilun Zhongyuan diqu shangdai de shuijing 试论中原地 区商代的水井” (Beijing: Zhongyang minzu daxue, 2015): 92; Wang Tao 王涛, “Shi qian shuijing de kaogu fenxi 史前水井的考古分析, ”Wen bo 文博 2001(2): 28-29.

32 Wang Tao, "Shi qian shuijing," 28-29.

33 See Wang Minhu 王毓瑚(ed.), Wang Zhen nong shu 王禎農書 (Beijing: Nongye chubanshe, 1981), 344.

${ }^{34}$ See James C. Scott, Against the Grain: A Deep History of the Earliest States (New Haven CT: Yale University Press, 2017).

35 Gao Tianlin 高天麟 and Zhang Daihai 张岱海, “Shanxi Xiangfen xian Taosi yizhi fajue jianbao 山西襄汾县 陶寺遗址发掘简报”, kaogu 考古, 1980(1): 18-31.
} 
Wheat remains have been discovered at more than thirty archaeological sites dated to before 3,000 BP in the areas in Northern China. In was most likely introduced to China via the Eurasian steppe around 4,500 BP, roughly contemporaneous with the Longshan period in the Haidai and Central Plains regions, and the Qijia Culture in Northwest region. ${ }^{36}$ Until the Han Dynasty (206 BCE - 220 CE), wheat was not consumed as a staple food on a significant scale in most regions of present-day China. ${ }^{37}$ Although wheat is mentioned in the late Shang oracle bones, it is referred to much less than millet, by both the Shang inscriptions and The Book of Songs. ${ }^{38}$ Wheat began to become more important after the Spring and Autumn Period. ${ }^{39}$

Just as foxtail millet cultivation had depended to some extent on technologies that modified the environment such as wells and metal tools, the rise of wheat also involved a series of modifications of, and adaptions to, the environment. Given its unbalanced precipitation, the Yellow River Basin was not well suited to growing wheat. The climate in most areas of Northern China is influenced by the Asian monsoons, which gives the Yellow River catchment basin in the Loess Plateau and North China Plain a dry winter and spring, and a rainy summer and autumn. Annual precipitation is in the range of 200 to $650 \mathrm{~mm}$, of which about 70 percent falls in June through September, while the annual evaporation reaches more than $1,100 \mathrm{~mm} .{ }^{40}$ Damage from summer floods could be avoided on land with poor drainage by sowing the winter wheat in the autumn after the rains, to be harvested in the late spring before next year's wet season. ${ }^{41}$ But the dry winter and spring also caused problems for wheat because it requires more water than both kinds of millet. ${ }^{42}$ A series of technical innovations in dryland farming that resulted in better access to irrigation and better soil moisture conservation were consolidated in the Warring States period and expanded after the Han Dynasty. ${ }^{43}$ In some cases these depended on state interventions, which is most likely to have been the case with major irrigation channels. From the Warring States period through the Tang Dynasty, there was a steady growth of irrigation infrastructure in the Wei River valley and in areas along the Yellow River. Important examples include, in the Wei River Valley, the Zhengguo 鄭國 channel from Warring States-era Qin Kingdom, to which were added, in the Han Dynasty, the Bai 白, Liufu 六輔, Lingzhi 靈軹, Wei 湋, Cao 漕, and Chengguo 成國

\footnotetext{
36 Zhao Zhijun, "Eastward Spread of Wheat into China - New Data and New Issues," Chinese Archaeology 9 no. 1 (2009): 1-9.

${ }^{37}$ Liu X. and Lightfoot, E., et al., "From Necessity to Choice: Dietary Revolutions in West China in the Second Millennium BC", World Archaeology 46, no. 5 (2014): 661-680.

38 Wang Yanling 王艳玲, “Jiaguwen guwu yu gengzuo lei ciyu yanjiu 甲骨文谷物与耕作类词语研究” PhD diss. (Hebei University, 2011): 20-24, 29-33; Qi Sihe 齐思和, “Mao shi gu ming kao 毛诗古名考.” Nongye kaogu 农 业考古, (2001:1): 202-224; Bray, Agriculture, 461-62.

39 Wan Guoding 万国鼎, Wu gu shi hua 五谷史话 (Beijing: renmin chubanshe, 1962), 10-14.

40 (Zhuang, 2015; Yellow River Conservancy Commission of the Ministry of Water Resources, 2011)

${ }^{41}$ Li, Fighting Famine, 92-94.

42 Cheng Bingwen 程秉文, “Zhongguo mizi chanye fazhan xianzhuang yu duice 中国糜子产业发展现状与对 策” in Zhongguo xiao zaliang chanye fazhan baogao 中国小杂粮产业发展报告, ed. Chai Yan 柴岩 and Wan Fushi 万富世 (Beijing: Zhongguonongyekexuechubanshe, 2007): 52-59.

${ }^{43}$ Liang Jiamian 梁家勉, Zhongguo nongye kexue jishu shigao 中国农业科学技术史稿, (Beijing: Nongye chubanshe, 1989): 117-139, 180-182.
} 
channels (Figure 2). The Han Dynasty also saw the construction of the Qianjin 千金 channel, recorded to be $200 l i$ (c. 100km) in Gansu's Hexi 河西 region. ${ }^{44}$ In the Ningxia section of the Yellow River, the Aishan 艾山 channel was built in the Northern Wei (386-534 CE). In the Henan section of the Yellow River, the Wangliang 王樑 channel was built in the Sui Dynasty (581-681), joining numerous smaller channels. ${ }^{45}$ Wheat also requires more nutrients than the millets. Iron tools and the use of bovids for ploughing, which proliferated in the Warring States period should have promoted more oxidation of humus in the soil for the release of nitrogen. ${ }^{46}$ To some extent, the development of different cultivars, which could have aided the process of adapting a foreign crop to China's environment might have been critical as well, though the emergence of Chinese wheat cultivars requires further study informed by archaeobiologists and historians. The Guang Chronicle (written about in 4-5th Century CE) and Essential Methods of the Common People refer to 'lushui wheat', 'red wheat', 'shanti wheat', 'middle-summer wheat'. ${ }^{47}$

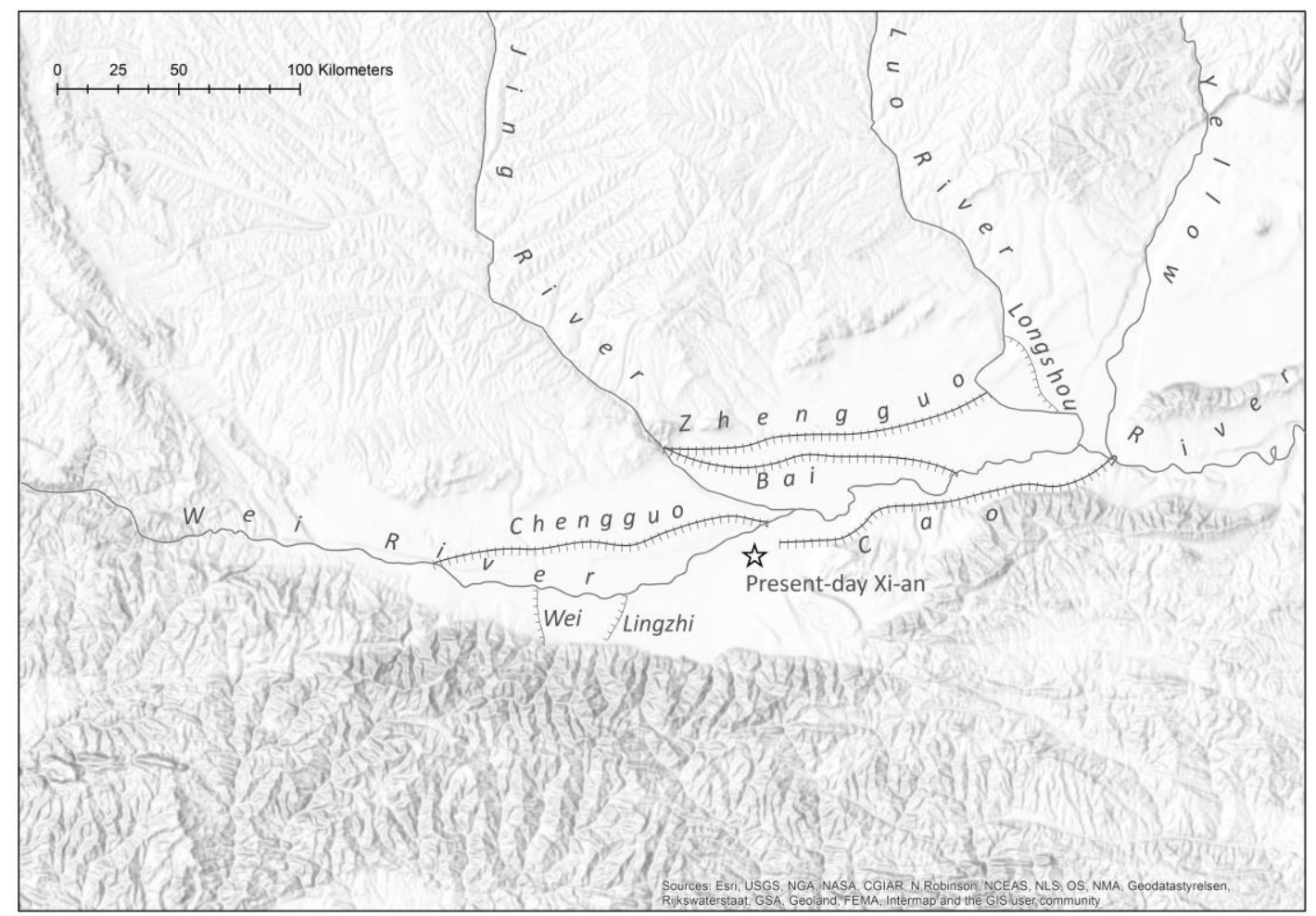

Figure 2: Map of major irrigation channels built by the Qin and Han states in the Wei River valley. The Liufu channel is not shown. Sources: Ma Zhenglin, "Qin Huang he Han Wu

\footnotetext{
44 Liang, Zhongguo nongye, 183.

${ }^{45}$ Liang, Zhongguo nongye, 117-139, 180-182.

46 R. S. Loomis, "Ecological Dimensions of Medieval Agrarian Systems: An Ecologist Responds," Agricultural History 52, no. 4 (1978), 479. Wheat was long known as a hungry cereal in China, see Bray, Agriculture, 476.

${ }^{47}$ See Li Hu 黎虎, “Wei Jin Nanbei chao shiqi zhu liang zuowu de zengjia 魏晋南北朝时期主粮作物品种的增 加," Zhongguo guojia bowuguan kan 中国国家博物馆馆刊, no. 11 (1989): 55-59, Jia Sixie, Liao Qiyu (ed.), Qi min yao shu xiao shi 贾思諰原著, 缪启愉校释. 齐民要术校释 (Beijing: Nongye chubanshe, 1982), 74, 92.
} 
Guanzhong nongtian shuili”; Liang Jiamian, Zhongguo nongye kexue jishu. ${ }^{48}$

Some historians suggest that one reason for growing wheat is that it yielded about twice as much per $m u$ as millet. ${ }^{49}$ Other scholars and most observations from late imperial and Republican China indicate the opposite. ${ }^{50}$ The question is nearly impossible to answer using observations of historical yields, as it requires controlled experiments in which wheat and millet are grown in the same conditions. This was precisely not what happened in the past. Wheat required more water, and was therefore more likely to have been grown on better, irrigated land than arid-tolerant millet. Wheat was also generally grown as a winter crop, sometimes immediately after harvest of another crop, both of which reduced its potential yield. Different crops also respond differently to fertilizer. The difference in typical growing seasons made it more difficult to compare wheat and millet yields than it was to compare yields of the different kinds of millet.

The reason for the initial spread of wheat that is mentioned in the ancient texts was its growing season. Millets were grown in spring and harvested in autumn, but wheat was planted in autumn and harvested in the late spring. By devoting some land to wheat and some to millet, farmers could spread work more evenly over more of the year, and spread the risk of bad weather, as European farmers did with three field rotations that included winter crops (wheat or rye) and spring crops (barley or oats). ${ }^{51}$ The Standard History of the Jin (Jin shu 晉 書), for example, indicated that the timing of the wheat season was the chief benefit of the crop: "the offset timing [in relation to other crops] of planting and harvest, makes [wheat] a supplement available to all, bringing great benefits." ${ }^{52}$ Although the use of the term 'supplement' ( $j i$ 濟) is suggestive of the later practice of growing wheat as an additional crop on the same land that grew millet, it is unlikely that this was practiced on any significant scale in the Jin (see below). Much more likely, all fields continued to have just one crop per year and some were set aside for wheat. It was a supplement in the sense that it added to the range of crops grown, or in the sense that the off-set growing season increased farmers' security. Warring States-era texts advocated crop rotation with one crop per year on each piece of land in a two or three-year cycle. The Spring and Autumn Annals of Master Lü called for one year growing foxtail millet and the next year wheat. ${ }^{53}$ Essential Methods of the Common People

\footnotetext{
48 Ma Zhenglin 马正林, “Qin Huang he Han Wu Guanzhong nongtian shuili 秦皇和汉武关中农田水利,” dili zhishi no. 2 (1975); Liang Jiamian, Zhongguo nongye kexue jishu, 180, 327.

49 Richard von Glahn, The Economic History of China, 131.

${ }^{50}$ Bray, Agriculture; Guo Songyi 郭松义, “Qingdai beifang han zuo qu de liangshi shengchan 清代北方旱作区 的粮食生产,”Zhongguo jingji shi yanjiu 中国经济史研究 no. 1 (1995): 25.

51 As Georges Comet notes, the European three-field rotations did not increase total yield — the advantage lay in the spread of risk. Comet, "Technology and Agricultural Expansion in the Middle Ages: The Example of France North of the Loire", in Medieval Farming and Technology: The Impact of Agricultural Change in Northwest Europe eds., Grenville G. Astill and John Langdon (Leiden: Brill, 1997), 29.

52 Jinshu 晉書, 'Zhi di ershiliu: shihuo', 22.

${ }^{53}$ Xia Weiying 夏纬瑛 (ed.), Lü shi chun qiu shang nong deng si pian xiaoshi 吕氏春秋上农等四篇校释
} 
also recorded some typical crop rotation systems: wheat $\rightarrow$ soybeans $\rightarrow$ foxtail millet; wheat $\rightarrow$ small bean $\rightarrow$ foxtail millet; wheat $\rightarrow$ turnip $\rightarrow$ foxtail millet, for which farmers presumably divided their land into sections, with different rotations on different sections. When millet harvests were poor, more winter wheat could be grown to compensate, a strategy adopted as early as the time of the compilation of the Book of Rites.

Despite the greater security it brought, farmers seem to have been unwilling to adopt wheat cultivation. The Standard History of the Han notes that in the reign of Emperor Wu (141 BCE - 87 BCE), the people of Guanzhong (in the Wei River valley) "did not want to grow wheat" (bu hao zhong mai 不好種麥)—a situation the compilers contrasted to what they believed had been the case in the Spring and Autumn era, though whether wheat cultivation was really more widespread in earlier times seems doubtful. ${ }^{54}$ One reason for farmers' reluctance to grow wheat could be because it was regarded as an unappetizing food in ancient China. In the Warring States era, wheat was usually eaten in the form of maifan 麥 飯, boiled or steamed granules, a form which later histories suggest was neither easily digested nor popular. ${ }^{55}$ An alternative interpretation for local opposition to wheat is that it was rooted in the cultivators' unwillingness to give up non-agricultural pursuits in the millet off-season and become year-round farmers, an interpretation consistent with James Scott's view that farming has often been an occupation forced upon less-than-free subjects by state authority. ${ }^{56}$ The idea of peasants being "taught" to grow winter wheat recurs in later writing often, and often without specification of what exactly was being "taught". ${ }^{57}$ Given that winter wheat had been grown in North China for many centuries, a critical reading of these claims should consider whether they reflect, rather than peasants' lack of knowledge about how to grow wheat, officials' preference for peasants to undertake year-round agricultural work instead of periods of seasonal off-farm work. The Han Emperor Wu sent official Fan Shengzhi to have people in Guanzhong to grow winter wheat in areas that were prone to flooding. ${ }^{58}$ Similarly, but much later, Xu Guangqi’s 徐光啟 (1562-1633) Ming dynasty agricultural treatise describes a community moving from occasional agricultural use of a swampy area of land to continuous cultivation using winter wheat, apparently as a result of Xu's instruction. ${ }^{59} \mathrm{Xu}$ presents this as an improvement in community's welfare, but historians must not accept these claims at face value, as the swampy land could have been used productively in ways that the Han emperors and Xu did not appreciate.

Official encouragement of winter wheat, which meant that agricultural tasks occupied

\footnotetext{
(Beijing: Nongye chubanshe, 1979): 37.

${ }^{54}$ Han Shu, 'shihuozhi', 23.

55 Q. Edward Wang, Chopsticks: A Cultural and Culinary History (Cambridge: Cambridge University Press, 2015), 49

56 See James C. Scott, Against the Grain: A Deep History of the Earliest States (New Haven CT: Yale University Press, 2017).

${ }^{57}$ Li, Fighting Famine, 92. Li cites Xu Guangqi 徐光啟, Nong zheng quan shu 農政全書 (1639), juan 25.

58 Han shu 漢書, 'Wu Di ji 武帝紀'.

59 Xu Guangqi 徐光啟, Nong zheng quan shu 農政全書, juan 25.
} 
people throughout the year, became a minor theme of statecraft in North China. This meant a new and important divergence in agriculture and agricultural governance between the North China Plain and the lands of peoples such as the Xiongnu, the Tangut, the Turkic peoples (before their entry into the area now known as Xinjiang), and the Mongols. There are no references to wheat in Han Dynasty descriptions of Xiongnu agriculture, and as Paul D. Buell and Eugene N. Anderson comment, the Mongols of the fourteenth century were less familiar with wheat and wheat-based food than with millet and sorghum. ${ }^{60}$ This had long-term implications for occupational structure on both sides of the boundary of winter wheat cultivation, with livestock and off-farm income remaining more important to farming households north of the boundary, while the winter-wheat growers specialized more in cropcultivation. The divergence grew larger in the late imperial era with the development of multiple cropping systems that depended on winter wheat, as discussed in the final section of this paper. John Lossing Buck's 1930s data, for example, showed that farming households in Gansu, Ningxia, and the northern parts of Shanxi and Shaanxi, all beyond the northern limit of the winter wheat area, earned an average of 26 percent of their income from off-farm sources. ${ }^{61}$ In winter-wheat regions of North China, an average of 16 percent of farming households' income came from non-agricultural sources. Moreover, although scholars have always been alert to the fluidity of the boundary between North China and the lands of pastoralists such as the Mongols and the borderlands in between, these spatial boundaries are nonetheless one of the most important geographical features in the history of north-eastern Asia. Everybody who has written on the subject has been careful to avoid environmental determinism, but the environment has typically been a starting point for discussions of this cultural frontier. Owen Lattimore, Dee Mack Williams and Peter Perdue have seen it as a hazy reflection of the boundary between ecological zones. ${ }^{62}$ Within the set of ecological elements that characterized these zones and their boundary, winter wheat was one of the most important.

In most agricultural systems, farmers use different processing and milling technology for wheat and millet. Millet grains are much smaller than wheat, barley, rye, or oats, and the millet pericarp is also more strongly attached to the endosperm. This requires a hulling process that is more laborious than the equivalent threshing and winnowing of wheat or rice. The relatively small number of European millet farmers use large pestle and mortar tools to hull millet, and similar tools (chu jiu 杵臼) were used in China, as well as a large rolling pin

\footnotetext{
${ }^{60}$ Paul D. Buell and Eugene N. Anderson, A Soup for the Qan: Chinese Dietary Medicine of the Mongol Era, As Seen in Hu Sihui's Yinshan Zhengyao (Leiden: Brill, 2010), 520

${ }^{61}$ Suiyuan and Qinghai have been excluded from this calculation, because of the dominance of livestock farming in these regions. Locations with zero percent income from off-farm sources have been excluded. John Lossing Buck, Land Utilization in China, volume 3: Statistics, (Nanking: The University of Nanking, 1937), 309-10.

${ }^{62}$ See Owen Lattimore, Mongol Journeys (New York: Doubleday, 1941) 127; Dee Mack Williams, "The Barbed Walls of China: A Contemporary Grassland Drama," The Journal of Asia Studies 55, no. 3 (1996): 669-670, Peter Perdue, China Marches West: The Qing Conquest of Central Eurasia (Cambridge MA: Harvard University Press, 2005).
} 
like tool. ${ }^{63}$ Millet flour can be made in the same pestle and mortars used for hulling, though in ancient China millet was usually not made into flour for dough. The rotary grindstones used for milling large grains like wheat are usually unsuited to millet, so their emergence in the Warring States era, and growth in popularity in the late Eastern Han Dynasty (25-220 CE) testify to the rise of both wheat cultivation and flour-based food produce. Grindstone and sieve technology improved incrementally through the late Han and early post-Han eras. ${ }^{64}$ Yeast and steamed buns made from wheat flour are mentioned in the second century CE Monthly Instructions for the Four Classes of People (Si min yue ling 四民月令). But the consumption of wheat flour was still not widespread among ordinary farmers as late as the seventh century, which suggests that grindstones remained less common than in contemporary Europe. Yan Shigu's 顏師古 (581-645 CE) annotations on the Han text Ji jiu pian 急就篇 ('Handy Primer', in Joseph Needham's gloss of the title) indicates that maifan was still the food of ordinary farmers in the open countryside (yeren nongfu 野人農夫). Wheat had become a common food, but outside cities, milled wheat had not. ${ }^{65}$ Yan indicated that maifan was cooked (chui 炊) momai 磨麥. Although mo can mean "milled"; in this context it probably meant wheat that had been coarsely ground with the chu jiu used for pounding millet. Yan used the character mian 䴮 to refer to the flour that was made into dough for steamed buns.

It is unclear that even the steamed dough foods were as popular before the Tang as some historians suggest. Monthly Instructions, for example, cautions against consumption of these foods by those with an excess of yin energy (yin qi 陰氣) in their digestive system. The impression given by quantitative estimates indicates substantial change in the Han Dynasty, though not enough to justify some scholars' notion that there was a general "culinary revolution" involving the rise of milled wheat flour and cooked dough. ${ }^{66}$ Richard von Glahn, for example, notes that "the proliferation of wheat largely came at the expense of legumes, notably soybeans." ${ }^{97}$ Since soybeans are estimated to have taken up around 25 percent of cultivated land in the Eastern Zhou, and declined to around 8 percent in the Han Dynasty, wheat could not have taken much more than, say, a quarter of the land area in the Han. ${ }^{68}$

Historians of the Tang and later periods have usually stressed that wheat was regarded as more appealing than millet (a "luxury grain" in Li's account of the Qing era). ${ }^{69}$ Wheat

\footnotetext{
${ }^{63}$ Bray, Agriculture, 445. For hulling tools in the Iberian peninsula, see Aitor Moreno-Larrazabal, Andrés TeiraBrión, Itsaso Sopelana-Salcedo, Amaia Arranz-Otaegui, Lydia Zapata, "Ethnobotany of Millet Cultivation in North of the Iberian Peninsula," Vegetation History and Archaeobotany 24, no. 4 (2015): 550-551. Similar tools are used to pound millet in India.

${ }^{64}$ Li Cheng 李成, “Huang He liuyu shiqian zhi liang Han xiaomai zhongzhi yu tuiguang yanjiu 黄河流域史前 至两汉小麦种植与推广研究,” PhD diss. (Xibei University, 2014): 126-132.

${ }^{65}$ Shi You 史游 with annotations by Yan Shigu 颜师古, “Ji jiu pian 急就篇”

66 Wang, Chopsticks, 49.

67 von Glahn, The Economic History of China, 131.

68 von Glahn, The Economic History of China, 131.

${ }^{69}$ Ling Zhang, The River, the Plain, and the State: An Environmental Drama: An Environmental Drama in Northern Song China, 1048-1128 (Cambridge: Cambridge University Press, 2016), 224; Lilian Li, Fighting Famine, 91.
} 
probably made the shift to a more desirable food during the Tang. The change in wheat culture was a complex shift with interrelated, and mutually-reinforcing cultural, economic, and technological dimensions. These included: 1) The Central Asian influence on Tang society, with Turkish cakes and pastries "became very popular" in the northern cities, followed by the rise of "flour based foods ... throughout the empire". ${ }^{70}$ 2) Further changes in wheat-specific technology, including grindstones. ${ }^{71}$ The development of grindstones involved a trans-Eurasian spread of design and technology, as medieval Chinese and European millstones came to share similar or the same patterns of furrows, which are not essential for milling but made it more efficient by channeled grain toward the outer edge (see figure 1 below). ${ }^{72}$ The maishan 麥釤 (a specialized wheat-cutting tool) also seems to have been developed around this time. ${ }^{73}$ 3) The rise in milling as a business enterprise among the nobility and monastic estates, which must have made milling more common. ${ }^{74}$ Wheat was also mentioned much more in Tang writing on agriculture than in the writing of previous eras, as Key Points for the Four Seasons (Si shi zuan yao 四時纂要 written in the late Tang Dynasty or early Five Dynasties, about 900 ) shows. ${ }^{75}$

\footnotetext{
${ }^{70}$ Mark Edward Lewis, China's Cosmopolitan Empire: The Tang Dynasty (Cambridge MA: Harvard University Press, 2009), 125.

${ }^{71}$ Li Falin 李发林, “Gudai xuanzhuan mo shi tan 古代旋转磨试探,” Nongye kaogu 农业考古, 1986(2): 146167.

72 See John Langdon, Mills in the Medieval Economy: England, 1300-1540 (Oxford: Oxford University Press, 2004), 173-74.

${ }^{73}$ See Bray, Agriculture, 341.

${ }^{74}$ Lewis, China's Cosmopolitan Empire, 125.

75 Chen Dongsheng 陈东生, “Shilun gudai Shandong maizuo shengchan de fazhan 试论古代山东麦 作生产的发展,” Gu jin nongye 古今农业, no. 1 (1993): 23-28.
} 


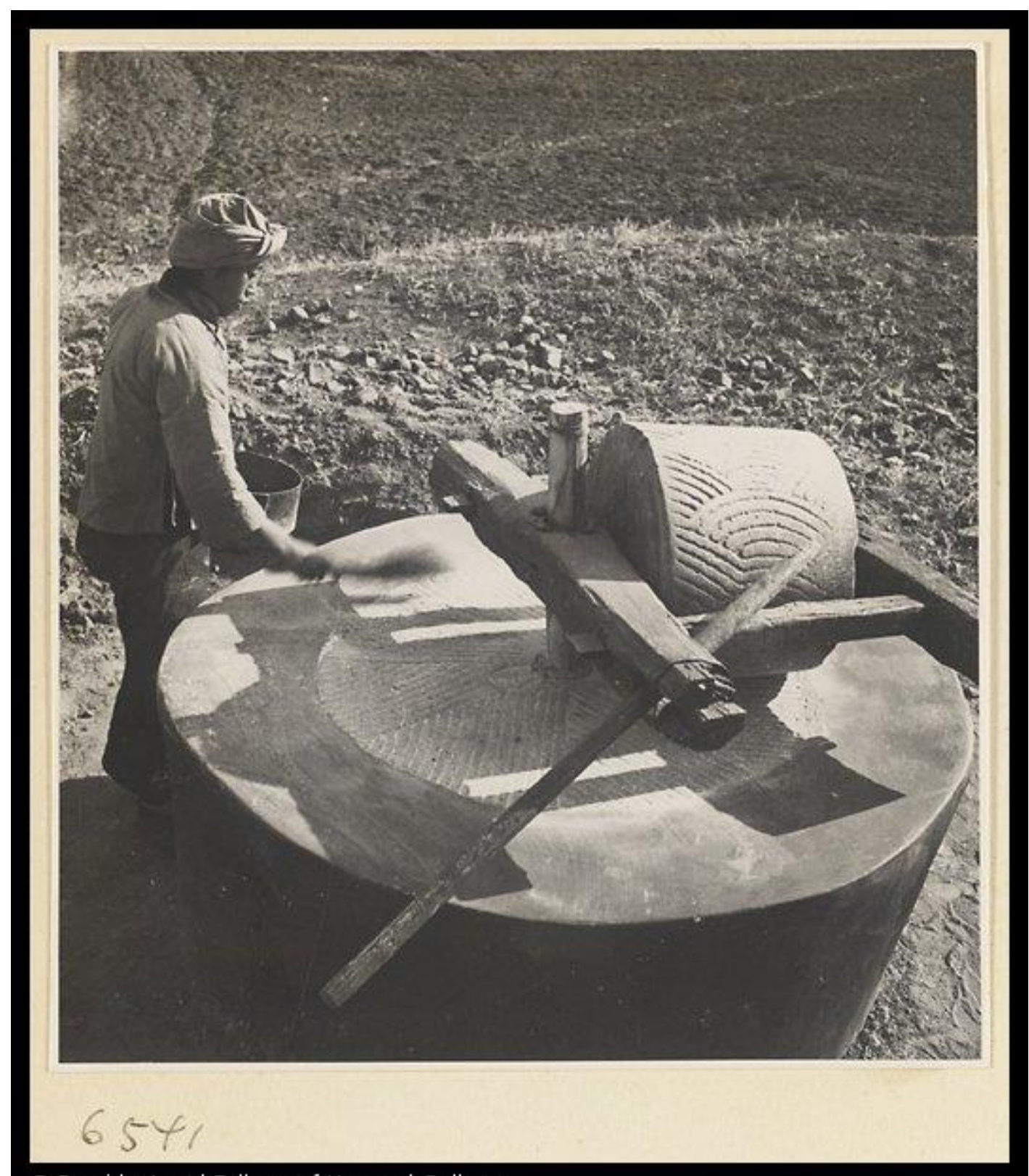

(c) President and Fellows of Harvard College

Figure 1: human-powered wheat grindstone. Source: The Hedda Morrison Photographs of China, 1933-1946, Harvard-Yenching Library. https://www.hpcbristol.net/visual/hv21-039.

There are similar examples in the Qiuci Cultural Museum in Xinhe County, Aksu Prefecture, Xinjiang Uighur Autonomous Region.

There is considerable disagreement about the extent of wheat and millet cultivation during the Tang and Song eras. Richard von Glahn suggests that in the Tang Dynasty "wheat decisively replaced millet as the dominant food grain" in the North. ${ }^{76}$ Ling Zhang, however, argues that in Hebei wheat remained a minor crop in comparison to millet throughout the Song. Zhang's view is based on several assumptions about cropping patterns, and also

76 von Glahn, The Economic History of China, 219. 
evidence from grain tax quotas. Since the mid-Tang, the government had collected taxes twice a year, once after the autumn harvest (mostly millet and soybean, straw and cash), and once after the summer harvest (mostly winter wheat, cloth, cash, and straw) ${ }^{77}$ In 1080 in Hebei, the grain tax quota was 11 times higher in the autumn than it was in the summer. ${ }^{78}$ Zhang notes the government might have decided to collect a smaller proportion of the wheat harvest than the millet, but that there is a lack of evidence for this. There are more grounds for speculation along these lines than she implies, as wheat was not an ideal tax crop because it is notoriously difficult to keep. ${ }^{79}$ Millet could be kept up to twenty years, which is why sixteenth century Venetian government granaries stored millet even though millet was a very minor crop in Europe ${ }^{80}$ Similarly, archaeological work on Tang-era granaries has uncovered large amounts of millet, but little or no wheat. In an excavation of Hanjia Granary in Luoyang (first built in 605), 259 underground food cellars were discovered, and Cellar 160 is estimated to have held 250 tons of foxtail millet. ${ }^{81}$ Given a preference for storing millet, it would have been logical for governments to have skewed tax collection towards the millet harvest. The total tax quota in autumn was 5.6 times the summer quota — still a big difference but much less than the difference in the grain quota for each season, which means a greater proportion of the summer tax was paid in cash, cloth, and straw; goods that were probably more useful to the state than wheat. Even so, Zhang's core argument is hard to dispute: the tax quotas are convincing evidence that millet was still the dominant grain in Hebei in the northern Song.

From later centuries, there are more records and more direct observations of the proportions of different crops. In the eighteenth century, Fang Guancheng described the crops grown in North China, reporting that although 70 percent of cultivated land in Shaanxi grew wheat, in some locations in Zhili only half did, and in others only 10-20 percent did. ${ }^{82}$ Buck's work in 1929-33 estimated that around 40 percent of the land in what he described as the "wheat region" grew of wheat. ${ }^{83} 13$ percent grew corn, 15 percent sorghum, and 27 percent millet. In Shaanxi and Shanxi, those three crops combined grew on 55 percent of the land, while wheat grew on 40 percent. Buck's surveys also suggested that, while the area devoted to wheat had remained steady since the 1900s, millet, sorghum, and barley had all been grown even more widely in the 1900s, and had since declined due to the rise of cotton, rapeseed, sesame and sweet potatoes. ${ }^{84}$ Assuming that Zhang Ling's observations about the minor position of wheat in twelfth century Hebei is also true for other regions of North China, then wheat cultivation must have grown gradually through the late imperial period. However, there

\footnotetext{
77 Zhang, The River the Plain, and the State, 232.

78 Zhang, The River, the Plain, and the State, 232.

79 Bray, Agriculture, 475.

${ }^{80}$ Fernand Braudel, The Structures of Everyday Life: Civilization and Capitalism, 15th-18th Century, volume 1 translated by Sian Reynolds (New York: Harper \& Row, 1981), 109

${ }^{81}$ Henan Museum 河南省博物馆 and Luoyang City Museum 洛阳市博物馆, “Luoyang Sui Tang Hanjia cang de fajue 洛阳隋唐含嘉仓的发掘”, Wen wu 文物 no. 3 (1972): 49-62.

${ }^{82} \mathrm{Li}$, Fighting Famine, 92-93.

83 Buck, Land Utilization in China, 211.

84 Buck, Land Utilization in China, 217.
} 
were two important factors that limited the proportion of wheat in the overall output of grain. Firstly, the great population expansion of the early modern era forced the expansion of agriculture into more marginal lands for crop cultivation. As we have seen, broomcorn millet was often the crop of choice for marginal land. Either kind of millet was a better choice for drier and less fertile soil. Secondly, as the next section will show, the most common multiple cropping systems that became more widespread with the growth of population in the Ming and Qing eras (1368-1911) relegated wheat to a relatively minor position, since they almost invariably entailed more of some combination of sorghum, soybeans, or millet than wheat.

The fact that wheat has probably never made up more than about 40 percent of North China's grain output had important implications for patterns of social and economic development. Even if Michael Mitterauer overstates the significance of large-scale milling enterprises for the development of what he calls post-medieval Europe's "special path" in world history, large mills were undeniably a very important component of Europe's economic landscape. ${ }^{85}$ As noted in the introduction of this paper, Bray has suggested that with the rise of wheat, North China began to look more like the economy and society of late medieval Europe - or, at least, as alike as it ever has. As various scholars have noted, the popularity of wheat in Tang China was associated with the rise of large-scale flour milling enterprises, apparently similar in scale to European establishments, initially often operated by monasteries, who were later joined by large numbers of landlords and merchants. ${ }^{86}$ Noting the apparently futile opposition to watermills from peasants alarmed at the diversion of water from irrigation to milling, some historians of medieval China have sometimes written as though the rise of large mills was part and parcel of a society in which wheat was an important crop. Large mills are not an inevitable feature of an agricultural landscape containing wheat, however, as late imperial China demonstrates ${ }^{87}$ Large-scale milling appears to have died out at some point after the Tang, the majority of China's wheat by the nineteenth century being ground by small backyard human or animal driven grindstones, like that shown in figure 3 below. Even in Europe, it was not really the case that large mills were an economic necessity. John Langdon estimates that in early fourteenth century England about 20 percent of grain was ground in smaller human or animal driven mills. ${ }^{88}$ In Europe, large mills dominated due to some unknown combination of market forces and the coercive power of nobility who forced peasants to bring their grain to manorial mill.

\footnotetext{
${ }^{85}$ Mitterauer, Why Europe? Ch. 1-2.

86 Jacques Gernet, Buddhism in Chinese Society: An Economic History from the Fifth to the Tenth Centuries, translated by Franciscus Verellen (New York: Columbia University Press, 1995 [1956]), 142-150.

87 See Lewis, China's Cosmopolitan Empire, 125.

88 John Langdon, Mills in the Medieval Economy: England 1300-1540 (Oxford: Oxford University Press, 2004), 126.
} 


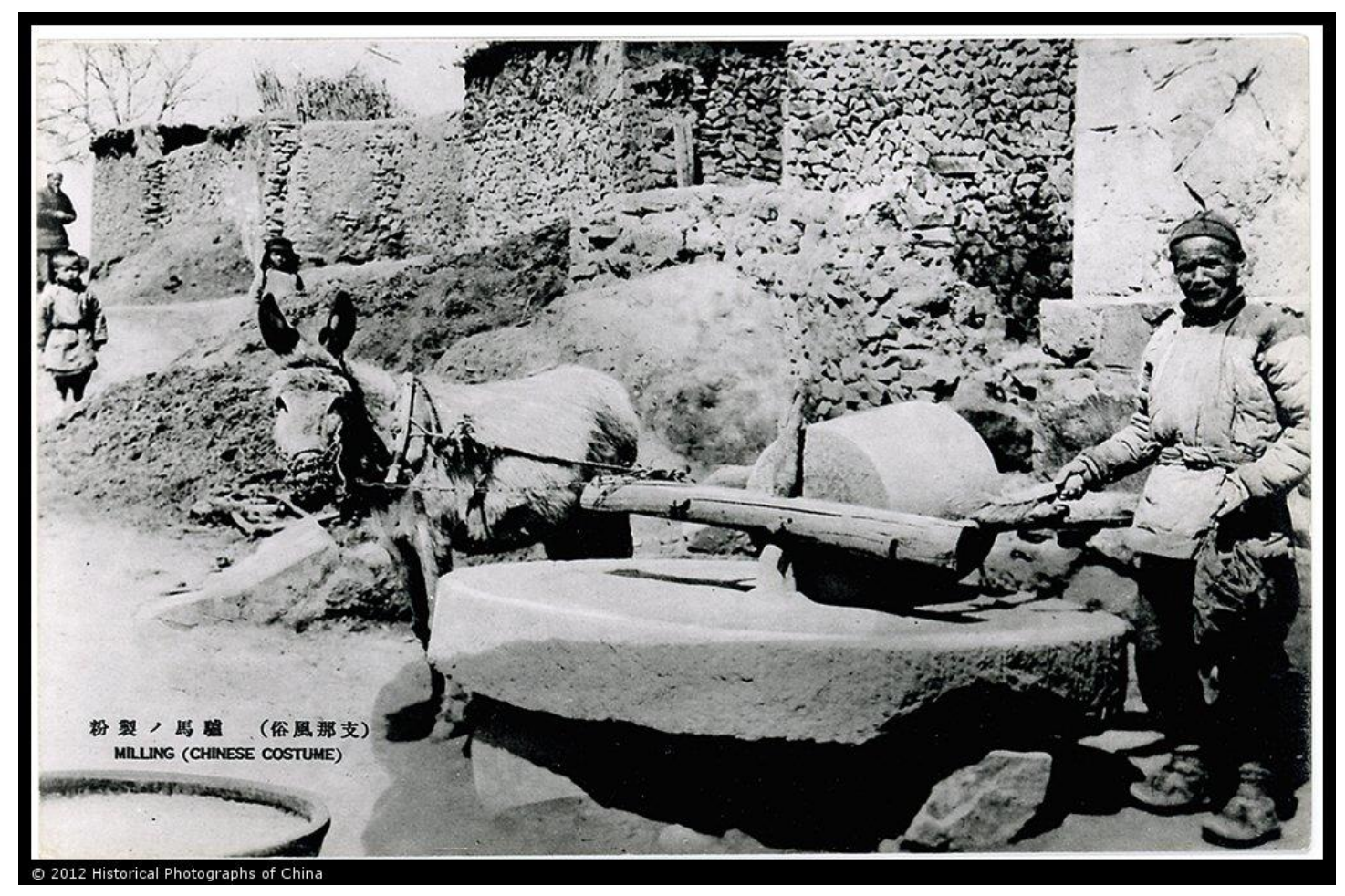

Figure 3: Donkey-powered grindstone, Japanese postcard from occupation-era Tianjin.

Source: University of Bristol Historical Photographs of China, Gr01-084.

https://www.hpcbristol.net/visual/gr01-084

There are probably several reasons why milling in China became a small-scale operation. Peasant and state opposition to watermills was possibly more successful in the long-run than Mark Edward Lewis suggests. ${ }^{89}$ However, the technology for windmills was known in China, so it is unclear why flour merchants could not have used that instead. Another possibility is that, with a smaller proportion of crops suited to large-scale milling than was the case in Europe, it would have taken a more extreme set of social and political forces to tip the balance in favour of large-scale milling in China than it did in Europe. Whereas all the main European grains can be ground in rotary grindstone mill after winnowing, large-grain grindstones are unsuited for much smaller millet grains. Water-driven pestle-and-mortars, presumably for pounding millet did exist, and may have looked similar to the water-driven rice pounder in figure 4 . Some of the Tang-era milling establishments used water-driven pestles, but further research is required to determine the significance of any advantage they brought. ${ }^{90}$ As we have seen, millet flour is usually made with the same tools used for hulling. Given that wheat made up only 30 to 40 percent of the total grain output in late imperial North China, the potential gains from outsourcing grinding work to milling enterprises were smaller for Chinese farmers than they were for European farmers who could outsource the

\footnotetext{
${ }^{89}$ Lewis, China's Cosmopolitan Empire, 125; Gernet describes the "imperial government's struggle against millowners", Buddhism in Chinese Society, 145-46. Gernet's short discussion remains the most extensive treatment of milling in pre-nineteenth century China.

${ }^{90}$ Gernet, Buddhism in Chinese Society, 144, 148.
} 
grinding of all their crops, allowing economies of scale in milling.

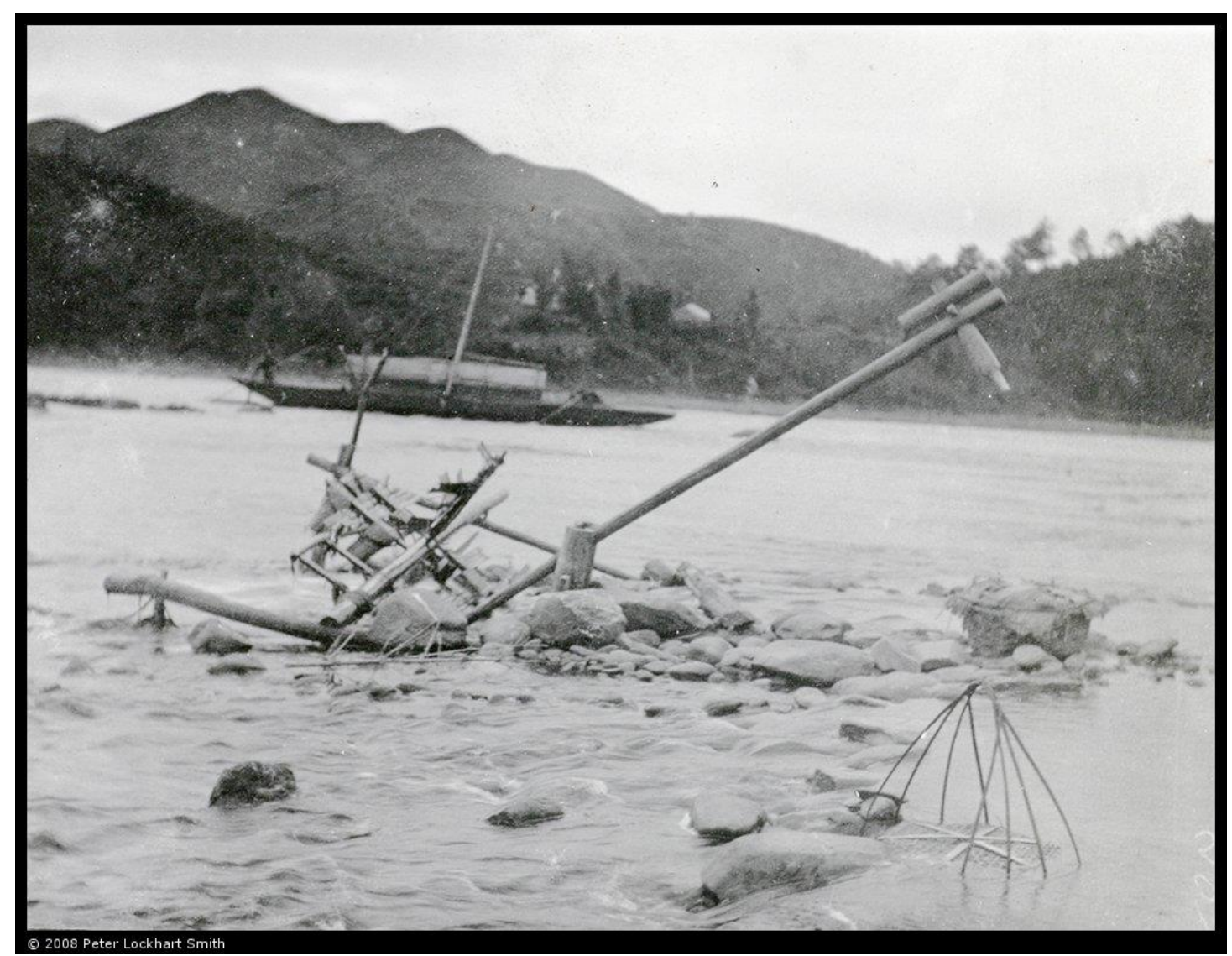

Figure 4. Water-driven rice pounder. From Banister Family Collection in the University of Bristol Historical Photographs of China Archive, Ba01-078.

https://www.hpcbristol.net/visual/ba01-078

\section{The Rise of Multiple-Cropping Systems.}

The next major transition in cereals cultivation in North China was the rise of multiplecropping regimes in the late imperial period. By the eighteenth century, multiple cropping regimes in North China were complex and varied considerably, even from village to village. Table 5 below indicates three cropping patterns recorded in the early-mid twentieth century.

\begin{tabular}{|r|r|l|}
\hline $\begin{array}{l}\text { Location / } \\
\text { planting season }\end{array}$ & Field A & Field B \\
\hline Pingxiang, Zhili ${ }^{91}$ & Wheat, barley \\
\hline Autumn & $(31$ percent of cultivated area) & \\
\hline
\end{tabular}

${ }^{91}$ Li, Fighting Famine, 102. 


\begin{tabular}{|c|c|c|}
\hline Spring & & $\begin{array}{r}\text { Sorghum, black beans, } \\
\text { millet, vegetables, soybeans } \\
(69 \text { percent of cultivated } \\
\text { area })\end{array}$ \\
\hline Summer & $\begin{array}{r}\text { Millet, hemp, indigo } \\
(23 \text { percent of cultivated area) }\end{array}$ & \\
\hline \multicolumn{3}{|l|}{ Yanshan, Zhili. ${ }^{92}$} \\
\hline Autumn & Wheat (55 percent of cultivated area) & \\
\hline Spring & & $\begin{array}{r}\text { Sorghum, black beans, corn } \\
\text { millet, vegetables, soybeans, } \\
(45 \text { percent of cultivated } \\
\text { area })\end{array}$ \\
\hline Summer & $\begin{array}{r}\text { Millet, hemp (53 percent of cultivated } \\
\text { area) }\end{array}$ & \\
\hline \multicolumn{3}{|c|}{ Qingchen, Shanxi ${ }^{93}$} \\
\hline Autumn (year 1) & \multicolumn{2}{|l|}{ Wheat } \\
\hline Summer (year 1) & \multicolumn{2}{|l|}{ Soybeans } \\
\hline Autumn (year 2) & \multicolumn{2}{|l|}{ Fallow } \\
\hline Summer (year 2) & \multicolumn{2}{|l|}{ Sorghum } \\
\hline Autumn (year 3) & \multicolumn{2}{|l|}{ Wheat } \\
\hline Summer (year 3) & \multicolumn{2}{|l|}{ Soybeans } \\
\hline Autumn (year 4) & \multicolumn{2}{|l|}{ Fallow } \\
\hline Summer (year 4) & \multicolumn{2}{|l|}{ Millet } \\
\hline Autumn (year 5) & \multicolumn{2}{|l|}{ Fallow } \\
\hline Summer (year 5) & \multicolumn{2}{|l|}{ Sorghum } \\
\hline
\end{tabular}

Table 5. Example multiple cropping regimes from early twentieth century North China.

Sources in Table.

There are some suggestions that double-cropping was common as early as the Northern Wei (386-534 AD). ${ }^{94}$ The evidence in support of this early comes from the Essential Methods of the Common People, which has the line, cited by Bray in support of early double cropping"for lesser beans it is usual to use land that has been cropped with wheat or barley, though I am afraid this is leaving it a little late [i.e. for the bean crop]." ${ }^{95}$ Because beans are a nitrogen fixing crop, double-cropping beans with wheat or barley would not have required as much extra fertilizer as two cereal crops would have. Also, as a relatively minor crop, it is unlikely

92 Li, Fighting Famine, 102.

93 T. H. Shen, Agricultural Resources of China (Ithica NY: Cornell University Press, 1951), 145.

94 Bray, Agriculture, 464.

95 Cited in Bray, Agriculture, 464. 
that most farmers grew beans on more than a small portion of their land (as we saw above, perhaps around eight percent in the Han), so double cropping these fields would not have required very significant amounts of extra labour. There is no evidence for widespread double-cropping with two cereals per year this early.

There is debate about when more intensive regimes appeared in Northern China. The earliest records of double cropping two cereals per year refer to regions further south and are from the mid-Tang and Song eras. As Bray notes, the first book to mention winter wheat being planted on land that had grown rice earlier in the year is the Man Shu, compiled around 860; though this describes the non-Chinese Nanzhao state in present-day Yunnan. ${ }^{96}$ The first unambiguous evidence for widespread double cropping with rice and wheat in the Chinesesettled lower Yangtze region is from the Song. ${ }^{97}$ Many scholars who have written about TangSong economic and technological innovation have focused more on the Yangtze region, though there is a common view the rise of the 'three crops in two years' rotation in the North also developed in the Tang Dynasty, either roughly simultaneous with, or possibly somewhat earlier than, the rise of double-cropping in the Yangtze region. ${ }^{98}$ The alternative view is that the more intensive cropping pattern in the North did not appear until the Song or even later. The most recent proponent of late-intensification is Ling Zhang, who argues that even in the Song, "the ratio of fields that afforded three crops in two years in a sustainable manner could not be high." 99

Overall, Zhang's view is more logical. Evidence from more recent history demonstrates that double-cropping is normally only attractive to farmers under specific circumstances. The cooler growing season of the second crop and the depletion of soil nutrients almost always make the yield from two crops per year less than twice the yield of one crop, even though labour requirements might be almost double and fertilizer costs even more than double. In present-day Hubei, for example, double-cropping requires farmers to work more than 70 percent more and spend 47 percent more on fertilizer to get around 46 percent more rice. ${ }^{100}$ In the present day, industrial production of fertilizer and modern transport infrastructure make the price elasticity of supply for fertilizer far lower than in contexts without substantial regional or inter-regional fertilizer markets. In the Song Dynasty, doubling the demand for fertilizer should have had a significant impact on per unit costs, so farmers would have paid a greater premium for the extra fertilizer required, further reducing productivity. A shift to double-cropping is therefore likely the result of one or both of two other trends: 1) Increasing population in relation to the land area used to supply that population's food, leading to food price increases that make the cultivation of an extra crop more worthwhile than whatever else

\footnotetext{
96 Bray, Agriculture, 464.

${ }^{97}$ Kent Deng and Lucy Zheng, "Economic Restructuring and Demographic Growth: Demystifying Growth and Development in Northern Song China, 960-1127," Economic History Review 68, no. 4 (2015): 1116.

98 von Glahn, The Economic History of China, 219.

99 Zhang Ling, The River, the Plain, and the State, 228.

${ }^{100}$ Gong and Zhang, "Betting on the Big", 9.
} 
people might do in the off-season. 2) The expansion of markets and transport infrastructure leading to new possibilities for food grown on highly productive land to be sold in territories with a comparative disadvantage in food production. Although market expansion could conceivably happen without population increases, historical examples of commercialization without population growth are rare. Beyond these environmental and market dynamics, some property regimes can encourage double-cropping. Rent, for example, was typically paid as a proportion of the first crop - by the twentieth century at rates well over 50 percent - whereas the second crop belonged to the tenant. Widespread tenancy under this system therefore encouraged multiple-cropping, but in North China tenancy was not especially widespread. As figure 2 shows, around 60 percent of the variation between different provinces' multiplecropping ratios in the mid-twentieth century can be explained by variation in their population densities. At the level of villages, the relationship between multiple-cropping and population density disappears, or at least, Buck's 1930s data gives no evidence of it. ${ }^{101}$ But this is testament to the efficiency of local markets. Given that much grain was traded between villages, villages with comparative advantage in grain production could expand multiple cropping, while people in places with land less suited to grain could concentrate more on offfarm employment or work seasonally on multiple-cropping farms elsewhere (i.e. the second condition for market-driven multiple-cropping expansion mentioned above). Since grain and labour movement between provinces was a much smaller proportion of the overall grain and labour markets, the population densities of provinces were a good predictor of their levels of multiple-cropping. In sum, at the scale of a province or regions composed of multiple provinces, the development of multiple-cropping was part of a multi-dimensional transformation that also involved population growth.

101 See John Lossing Buck, Land Utilization in China, vol. 3: Statistics (Nanjing: University of Nanking, 1937). 


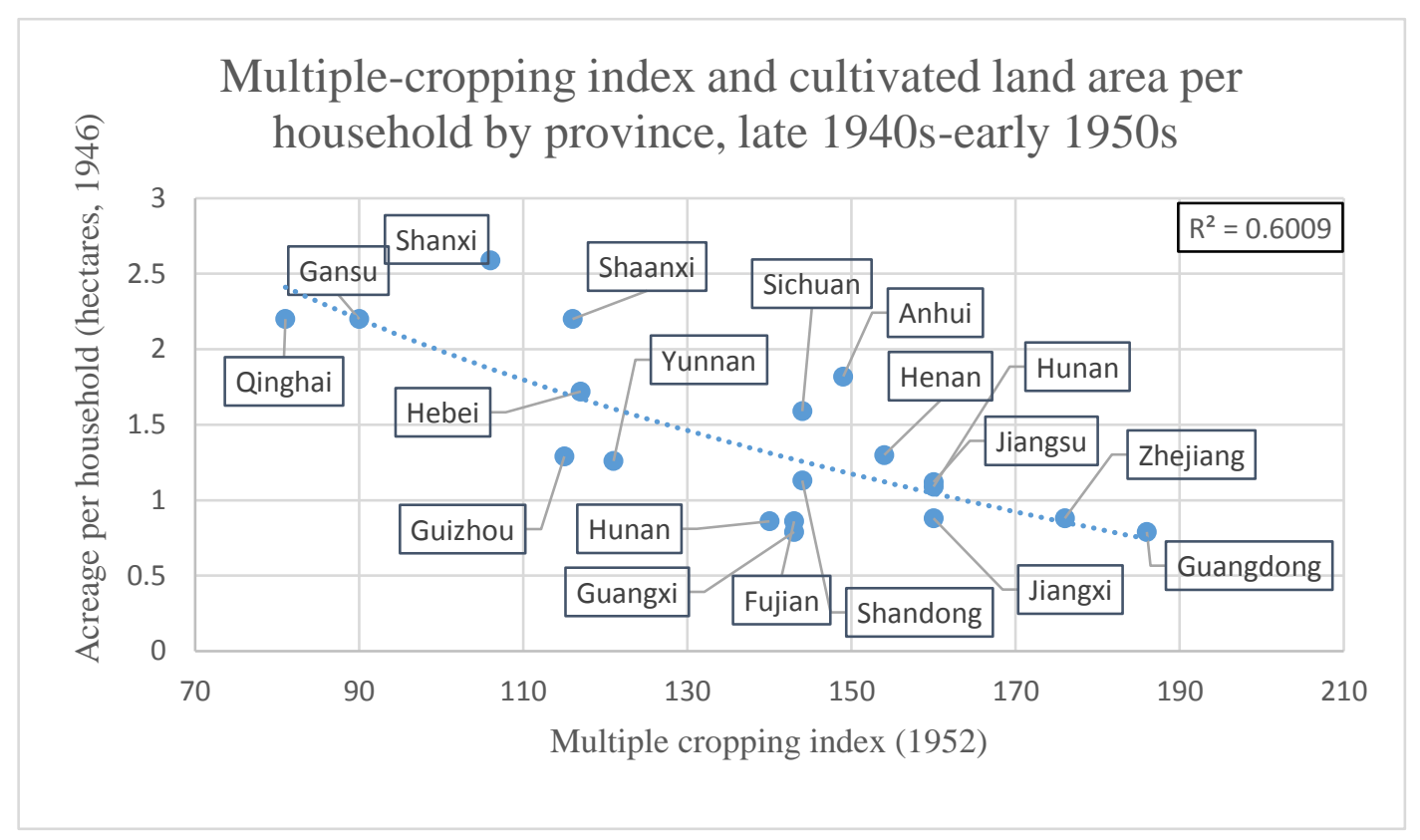

Figure 2. Provinces by multiple cropping index (1952) and acreage per household (hectares, 1946). Sources: T. H. Shen, Agricultural Resources of China; Liu Xunhao, "Lun woguo gengdi zhongzhi zhishu". ${ }^{102}$

Since the population of North China is estimated to have been stable between the Han Dynasty and the Ming Dynasty, there is no reason to expect that multiple-cropping expanded much during this time. From a peak of about 63 million in the mid-Han, the Chinese population declined to around 50 million around 600 , before steadily rising again from the early Tang Dynasty, to reach a peak of around 115 million in the Song. ${ }^{103}$ Although the population in the Song Dynasty was considerably higher than at any previous time in history, almost all the population growth was in the Yangtze region. Hebei's population in 1102 was marginally smaller than it was in 754 , which means that it was probably no larger it had been in the Han Dynasty either. ${ }^{104}$ In these circumstances, it is unclear why farmers in the North would have begun more labour-and fertilizer-intensive cropping patterns as a routine, rather than as an emergency measure in case of a poor harvest. If double-cropping did become widespread in the Song in the North, it is unclear why the population did not increase, as is normal in societies that experience a significant growth in food supplies.

Population growth was partly a consequence of increasing food production, but it was also a cause: it provided an incentive to cultivate more land more intensively, and it provided

102 T. H. Shen, Agricultural Resources of China (Ithica NY: Cornell University Press, 1951), 142; Liu Xunhao 刘 巽浩, “Lun woguo gengdi zhongzhi zhishu (fuzhong) de qianli 论我国耕地种植指数（复种）的潜 力,” Zuowu zazhi 作物杂志, no. 3 (1997): 3.

103 Albert Feuerwerker, "Chinese History in Comparative Economic Perspective" in Heritage of China: Contemporary Perspectives on Chinese Civilization, ed. Paul S. Ropp (Berkeley: University of California Press, 1990), 226-27.

104 Zhang, The River, the Plain, and the State, 190. 
the labour power to overcome the bottleneck during the key autumn and early summer periods in which, under double-cropping regimes, one crop must be harvested, the land prepared, and the next crop planted. ${ }^{105}$ Twentieth century research calculated that in Henan, Shaanxi, and Shandong, there were only about 15 days to do this work in the autumn busy period. ${ }^{106}$ In Luancheng County in Hebei there were only 6 or 7 days to finish the wheat harvest in the summer in order to plant the next crop in time. ${ }^{107}$ Research conducted in 1948 by the University of Nanking found that it took one adult five hours to harvest a $m u$ of wheat with a scythe. ${ }^{108}$ Then the same amount of time to plough the same area with a buffalo or ox. ${ }^{109}$ Then another five hours to do the harrowing with a draft animal, and another hour to do the seeding with the animal and a 5-row drill. Assuming the hypothetical adult had an ox, by working 12 hour days and assuming no interruptions from bad weather they would have enough time for two plantings on only $11 \mathrm{mu}$ in North China without help from more workers and more draft animals. By the twentieth century more workers were plentiful in many places in North China, but this was not so in even the late Ming Dynasty, when there were $21.7 \mathrm{mu}$ per person in Wei County, Zhili. ${ }^{110}$ Most parts of northern China were more densely populated: census records from 1578 suggest around $11.2 \mathrm{mu}$ per person over the whole of Shandong and Hebei. ${ }^{111}$ Even so, two plantings per year on all land would have required every woman, man, and child to work 12 hour days in the fields every day of the 15 day harvest-to-planting window, which is clearly unrealistic. The labour bottleneck to multiplecropping was eased incrementally by population increases in the Qing dynasty, and the 'three crops in two years' systems became widespread in Shandong and Henan by the early twentieth century. Nevertheless, peak-season labour demands remained one of the key limitations on the further intensification of agriculture in the North, even in the twentieth century. ${ }^{112}$

The spread of multiple-cropping in late imperial North China is thus an important and underexplored aspect of China's environmental and economic history. Of particular significance is the question of what other social and technological changes it involved, besides the population increase. Almost certainly, it entailed North Chinese communities

\footnotetext{
105 Zhang Ling also highlights labour as a constraint on multiple-cropping during the Song Dynasty, The River, the Plain, and the State, 226-27.

106 "Guanyu Lu, Yu, Shaan, san sheng pingyuan hanzuo diqu ji ge nongye shengchan hezuoshe tan chan tan shou he nongye jixiehua wenti de diaocha baogao", 6 Oct 1957, QZH:194,MLH:2,AJH:704, Shaanxi Provincial Archives.

107 Yan Ruizhe and Liu Tianfu, "Dui nongye jixiehua jingji tiaojian de tantao" in Zhongguo nongye jingji xuehui nongye jixiehua jingji yanjiuhui (ed.) Nongye jixiehua jishu jingji wenti (Beijing, Nongye chubanshe: 1979), 14.

108 L. T. Woo, "The Farm Machinery Program for China" p. 3, QZH:23, AJH:2681, Second Historical Archives of China (Nanjing).

109 The research was conducted with buffalo, but other studies have shown little overall difference between the output from buffalo and oxen, even though buffalo are somewhat slower, see Anne R. Pearson, "A Comparrison of Draught Cattle (bos indicus) and Buffaloes (bubalus bubalis) Carting Loads in Hot Conditions," Animal Science 49, no. 3 (1989): 355-63.

${ }^{110}$ Li, Fighting Famine, 84.

111 Philip Huang, The Peasant Economy and Social Change in North China (Stanford: Stanford University Press, 1985), 324, 327.

112 Bray, The Rice Economies, 156.
} 
becoming more connected with regional and inter-regional fertilizer markets, in a process probably similar to what has already been described for the lower Yangtze region. ${ }^{113}$ There were likely other changes as well. To support the description of North China as an "ecological disaster area" in 1900, Kenneth Pomeranz argues that peasants have been drilling "deeper and more expensive irrigation wells" since at least the eighteenth century. ${ }^{114}$ Partly, this was to support cotton cultivation, but it multiple-cropping of cereals must also have increased demand for water to some extent.

\section{Crops and Civilization in the Longue Durée}

In the very long term history of cereals cultivation in North China, there were several phases of increasing land productivity before the twentieth century, each part of broader societal shifts involving population growth. The first, around $5000 \mathrm{BCE}$, involved a shift from broomcorn to foxtail millet, as well as the proliferation of well construction and advanced stone tools. The second, in the first millennium BCE through the Han Dynasty involved the spread of metal tools, bovids, and large-scale irrigation in the Wei River valley and along the Yellow River. The third, in the Ming and Qing dynasties involved the adoption of multiple cropping, and (beyond the scope of this paper) the cultivation of potatoes. All these transitions happened gradually, over centuries, or probably longer in the case of the first. Whether any change happened rapidly enough to be described as a 'revolution' depends on the time-scale of the analysis and on more quantitative data than we currently have. Historians of agriculture have sometimes been over-eager to apply the term 'revolution' to transitions that unfolded over a much longer time than their studies suggest. Mark Elvin, for example, argues that one component of medieval China's (eighth to twelfth centuries) "revolution in farming" was "better milling machinery [that] led to the widespread cultivation of wheat in place of millet". ${ }^{115}$ However, both grindstones and wheat had been spreading since the Han Dynasty, and there is insufficient evidence to support a claim that change accelerated after the eighth century.

Economic historians who write about agriculture have tended to focus on changes that increase productivity, either in terms of land or labour. This either misses important changes, or, where attempts are made to cast transitions as a productivity-increasing, misrepresents what really happened. The rise of wheat cultivation is one example. This began and unfolded simultaneously with the second major transition described above, and depended on it to some extent because the water and nutrient demands of wheat were better catered for with irrigation and ploughing with bovids and metal tools. Wheat itself did not increase land productivity

\footnotetext{
113 Kenneth Pomeranz, The Great Divergence: China, Europe, and the Making of the Modern World Economy (Princeton: Princeton University Press, 2000), 226.

114 Pomeranz, The Great Divergence, 237

115 Elvin, The Pattern of the Chinese Past, 113.
} 
until the Ming Dynasty, because the use of land for two cereals crops per year is unlikely to have happened on any significant scale in North China until the late imperial population boom. Indeed, setting aside some land for a winter wheat crop could well have decreased land productivity, as most observations from late imperial China suggest that winter wheat crops had lower yield than summer millet. Until the Ming, winter wheat was a risk-reducing crop. If exceptionally bad weather at a crucial time reduced a harvest by fifty percent, the overall effect on a household that divided their land evenly and had two harvests per year would be a loss of only around one quarter, as long as it was a once in a year event. The division of land between crops also reduced seasonal peaks and troughs in labour demand in agriculture. Some evidence suggests that imperial governments and other members of the elite were more concerned that farmers adopt winter wheat than were the peasants, who either valued their off-season activities, or the taste of millet, or the higher yields that, in years of good weather, came from devoting all of their land to a summer crop.

Within the bigger picture of millet and wheat in China, there are several unanswered questions that deserve further research: 1) the substantial literature on water and hydraulic infrastructure has not given much attention to well drilling before the twentieth century (and, considering the seriousness of the depletion of North China's water table, there is not much scholarship on twentieth century well digging either). Well construction potentially played an important part in the spread of foxtail millet, wheat, and multiple cropping, and is worthy of further consideration. 2) The history of cultivars is barely begun to be written. In her history of American agriculture, Courtney Fullilove has recently highlighted how the "soft white winter and spring varieties of [of wheat] that flourished on the Eastern Seaboard couldn't survive the harsh conditions on the plain." 116 The colonization of the West thus required new varieties, the spread of which is an important element of America's environmental history. The comparable history of the wheat cultivars that flourished, or did not, in various regions of China, and how they got there, remains to be written. 3) The history of grain processing and milling is generally under-researched, even though some historians of Europe have argued that the rise of large-scale milling enterprises was crucial for the development of Europe's 'special path' in the early modern era. The large-scale milling enterprises that had existed in China during the Tang era died out at some point thereafter, for reasons that have yet to be satisfactorily explained. It is likely that further research will find a number of factors were responsible, but it could be that, with a much smaller proportion of the crop output suitable for milling on grindstones than Europe, it would have required a more powerful set of political or social circumstances to work in favour of large-scale milling for it to survive.

\footnotetext{
116 Courtney Fullilove, The Profit of the Earth: The Global Seeds of American Agriculture (Chicago: The University of Chicago Press, 2017), 101.
} 